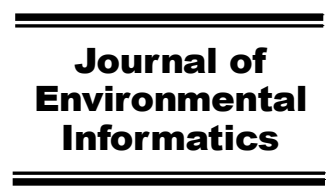

www.iseis.org/jei

\title{
Impact Study of Impoundment of the Three Gorges Reservoir on Salt-Water Dynamics and Soil Salinity in the Yangtze River Estuary
}

\author{
W. P. Xie ${ }^{1}$, J. S. Yang ${ }^{*}$, R. J. Yao ${ }^{1}$, and X. P. Wang ${ }^{1 *}$ \\ ${ }^{I}$ State Key Laboratory of Soil and Sustainable Agriculture, Institute of Soil Science, Chinese Academy of Sciences, Nanjing 210008, China
}

Received 30 May 2019; revised 28 March 2020; accepted 12 April 2020; published online 30 June 2020

\begin{abstract}
As the largest hydropower project in China, the impact of the Three Gorges Project (TGP) on the ecological environment has aroused public attention and has been studied from various aspects. After the TGP was operated, seasonably adjusted runoff by the Three Gorge Reservoir (TGR) might cause great changes of hydrological regime in the lower reaches of the Yangtze River, especially the estuarine areas where seawater intrusion is strong and salt-water environment is complicated. The salt-water dynamics in this region will be greatly influenced in response to the operation of TGP. In order to study the impact of the project on salt-water dynamics and soil salinity, a field experiment has been carried out in the Yangtze River Estuary (YRE). This paper seeks to investigate the influence of the TGR on salt-water dynamics and soil salinity in YRE through the analysis of the relationship between the impact factors of saltwater dynamics in the estuary area. Results showed that the estuarine runoff was closely related to the impoundment process, and the estuarine runoff was one of the most important factors that influenced salinity dynamics of water and soil in the estuary. Results showed that discharge of the TGR was affected by its water storage speed, and runoff at Datong station in the estuary was significantly correlated with the reservoir discharge. The reservoir discharge affected Datong runoff and the lag time of influence of the TGR on Datong discharge is about 8 to 9 days. Runoff at Datong station influenced the river water level in the estuary, and impact of the river runoff on the river water level was delayed around 13 days. The lag time of the influence of the impoundment process of the TGR on the estuarine water level is about 20 days. The discharge decrease of the reservoir reached $3600 \mathrm{~m}^{3} / \mathrm{s}$ during the impoundment period in 2011 , and it would cause about $3500 \mathrm{~m}^{3} / \mathrm{s}$ flow decline at Datong station with 8 days lag. It will result in $15.6 \mathrm{~cm}$ drop in the water level and $4.26 \mathrm{mS} / \mathrm{cm}$ increase in river water electrical conductivity (EC) in the estuary, which indicated the increase risk of seawater intrusion intensity in the estuary. Significantly positive correlation between river water salinity and ground-water salinity was also observed, and influence of the river water salinity on groundwater salinity increased gradually from the river bank to the inland. Significant correlation existed between groundwater salinity and soil salinity in different soil layers, with the closest relation in the deep layers. Monitoring results showed that salinity of river water, groundwater and soil under impoundment process performed higher than that of non-impoundment process, and it could be inferred that the impoundment process has a certain impact on the salt-water dynamics and soil salinity in the estuary. In summary, soil and groundwater salinity were affected by the TGR, and risk of soil salinization increased.
\end{abstract}

Keywords: Three Gorges Reservoir, impoundment process, Datong runoff, river water level, river salinity, groundwater salinity, soil salinity

\section{Introduction}

Influence of large hydropower projects on environment has been a hot topic of global concern. Such kind of mega projects provides society with many benefits but simultaneously adverse impacts on the environment (Asmal, 2000; Shahin, 2006). However, dams have been built over most large rivers at the central and upper reaches in recent decades, dramatically changing stream hydrology and sediment delivery, resulting in changes in hydraulics and river delta development trend at the lower reaches (Liu et al., 2018; Rahman et al., 2018). Dams cut off the river systems, and interrupt the migration of aquatic

*Corresponding author. Tel.: +86 25 86881222; fax: +86 2586881222 .

E-mail address: jsyang@issas.ac.cn (J. S. Yang);

xpwang@issas.ac.cn (X. P. Wang)

ISSN: $1726-2135$ print/1684-8799 online

(C) 2020 ISEIS All rights reserved. doi:10.3808/jei.202000432 organisms and alter their life cycles (Arthington et al., 1991). Also, dams promote downstream erosion, modify temperature regimes both within the reservoir and downstream, and cause changes in seasonal river flow condition and reduce sediments of the river (Ibàñez et al., 1996; Clarkson et al., 2000; Zahar et al., 2008; Dai et al., 2008a).

There are already some studies regarding other environmental effects that include changes in flooding (Dehkordi and Nakagoshi, 2004), hydrology patterns landslide, earthquake occurrences, loss of biodiversity, and changes to aquatic and terrestrial flora and fauna (Mumba and Thompson, 2005; Yang et al., 2005; Ashraf et al., 2007; New and Xie, 2008). The monthly flow characteristics between natural rivers (76 stations) and reservoir-regulated rivers were compared and result revealed that dams alter all monthly flow characteristics but the extent of the modifications is variable (Lajoie et al., 2007). Dam construction in the upstream of a river and water conserveancy projects built along large rivers, has resulted in sea- 
sonal changes in downstream freshwater discharge, leading to adjustments in the function of fluvial and estuarine hydrology (Lu et al., 2011; Mei et al., 2015). The adverse environmental impacts of hydraulic projects on Mediterranean watercourses have been raised since the effects of the Aswan dam on the Nile were revealed. It is suggested that dam managers should mimic, as much as possible, the natural river flow, in order to minimize the impact on downstream ecosystems. Management efforts should not be restricted to the areas upstream of the dam, but should also encompass the estuary and adjacent coastal area (Morais et al., 2009). Seasonal flow reduction resulted from dam's impoundment may cause seawater intrusions in estuary of rivers, such as the Nile River and the Yangtze River, etc.

Completion in 1968 of the Aswan High Dam on the Nile River in Egypt has profoundly affected the entire Nile Basin in Egypt and the Sudan, and negative impacts included alteration of shoreline ecology, regulation of the once-variable water flow (with reduction of flow to the Mediterranean by as much as 100 $\mathrm{cu} \mathrm{km} / \mathrm{yr}$ ) and also increased irrigation canal salinity (White, 1988). Practically all of its irrigation water came from the River Nile, and the local adverse water quality situation at lower order canals gave rise to the soil salinization (Kotb et al., 2000). The effect of various management alternatives for the reservoir on water table levels, thickness of freshwater and the position of the interface were considered in numerical modeling of saltwater intrusion (Bobba, 2002). The impact of an interbasin water transfer on the estuary gate area may include an increase in salinity in the delta and estuary (Ibàñez and Prat, 2003).

As the largest hydropower project in China, the benefits of the Three Gorges Project (TGP) are indeed substantial, but the environmental impacts of the TGP on the Yangtze River ecosystem can not be ignored (Wu et al., 2019). There are some studies on the environmental impact of the TGP on the Yangtze River. Noticeable changes in the microbial community structure in the estuary and the East China Sea were observed 2 months after the storage process in June 2003. Although causes for these changes could be multiple, the sudden decrease of river runoff and an ensuing intrusion of East China Sea ocean currents were postulated to be among the major ones (Jiao et al., 2007). From November 2002 to 2006, five cruises were undertaken in the Yangtze River Estuary and the adjacent East China Sea to compare the nutrient concentrations, ratios and potential nutrient limitation of phytoplankton growth before and after impoundment (June, 2003) of the Three Gorges Dam (TGD) (Chai et al., 2009). 54\% of the water flux was lost at Datong during September 20 to October 27, 2006, in comparison with the same period in 2005, and it was estimated that the impounding of the TGD contributed $9 \%$ of flow loss at Datong of the Yangtze River in 2006 (Dai et al., 2008b). During the average annual cycle of TGD's regular flow control in $2009 \sim 2012$, downstream Yangtze level variations were estimated to have been reduced by $3.9 \sim 13.5 \%$ at 15 studied gauging stations, manifested as evident level decrease in fall and increase in winter and spring (Wang et al., 2013). There also exists a negative correlation between estuarine salinity changes and runoff from the upper reaches. Runoff is an important factor influencing salty water intrusion (Jiang and Yan, 2003). Impoundment of the TGP will affect the runoff conditions, thus intensify the seawater intrusion in the estuary, especially in dry seasons and dry years (Chen and $\mathrm{Xu}, 1995)$. The large variations of river discharge have significantly affected downstream discharge (Yang et al., 2010), and the negative effects of TGP appear only in October of the dry season, which allows saltwater intrusion to occur early in advance (An et al., 2009). The results showed that the TGR advanced the timing of seawater intrusion and slightly increased its intensity during the autumn season (Qiu and Zhu, 2013). The results in Cai's study indicated that the strongest impacts occurred during the autumn and winter, corresponding to a substantial reduction in freshwater discharge during the wet-to-dry transition period and slightly increased discharge during the dry season (Cai et al., 2019). The possible impacts of the Three Gorges Dam on the monthly variation of water discharge to the sea are discussed with special emphasis and some previous studies indicated that in a dry season the water discharge to the sea is greatly reduced and results in strong salt-water intrusion in the estuary (Chen et al., 2001).

Considerable changes in the downstream freshwater discharge were caused by the TGD due to its seasonal allocation mode for flood control, irrigation, and power generation. Seawater intrusion is an important problem in the Yangtze River Estuary, and it is largely determined by the runoff from the upperreaches of the Changjiang River. Before the Three Gorges Dam was built, the characteristic of the natural flow distribution was most in summer, less in spring and autumn and winter. Moreover, the estuarine seawater intrusion occurred in autumn, spring and winter, when the flow reached the least. However, after the Three Gorges Reservoir, the natural flow regulation was changed and time of dry season was altered. Meanwhile time and the intensity of saltwater intrusion were changed. Due to the estuarine aquifer structure, there is a strong hydraulic exchange between river water and groundwater. Groundwater depth and salinity are affected by the river water level and river salinity. Since groundwater is the lower boundary condition of surface soil salinity, and also groundwater is closed related to river water, it is the important link between soil and river water. As the river water level and salinity changes, groundwater environment and soil salinity would be affected.

More serious seawater intrusion occurs in North Branch of the Yangtze River because of less runoff compared with that in the southern branch (Chen et al., 2011). Although previous studies have discussed the influence of water regulation by the TGR on the upper reaches and the seawater intrusion (Chen and Xu, 1995; An et al., 2009), they only focused on the impact on seawater intrusion and fresh water supply, and research concerning impact of dams on soil salinity was studied, such as Aswan Dam. Therefore, research on the influence of the TGP on salt-water dynamics and soil salinity in the estuary was needed. In view of the current hydrological regime of the estuary, the most important issue is to study the impact of the runoff from the upper reaches on salt-water dynamics and soil salinity in North Branch of the Yangtze River Estuary (YRE). The impact study of the TGP on the estuary in this paper was set in the North Branch of the YRE and was started since 1998. Primary results of our research showed that in dry years after the Three 


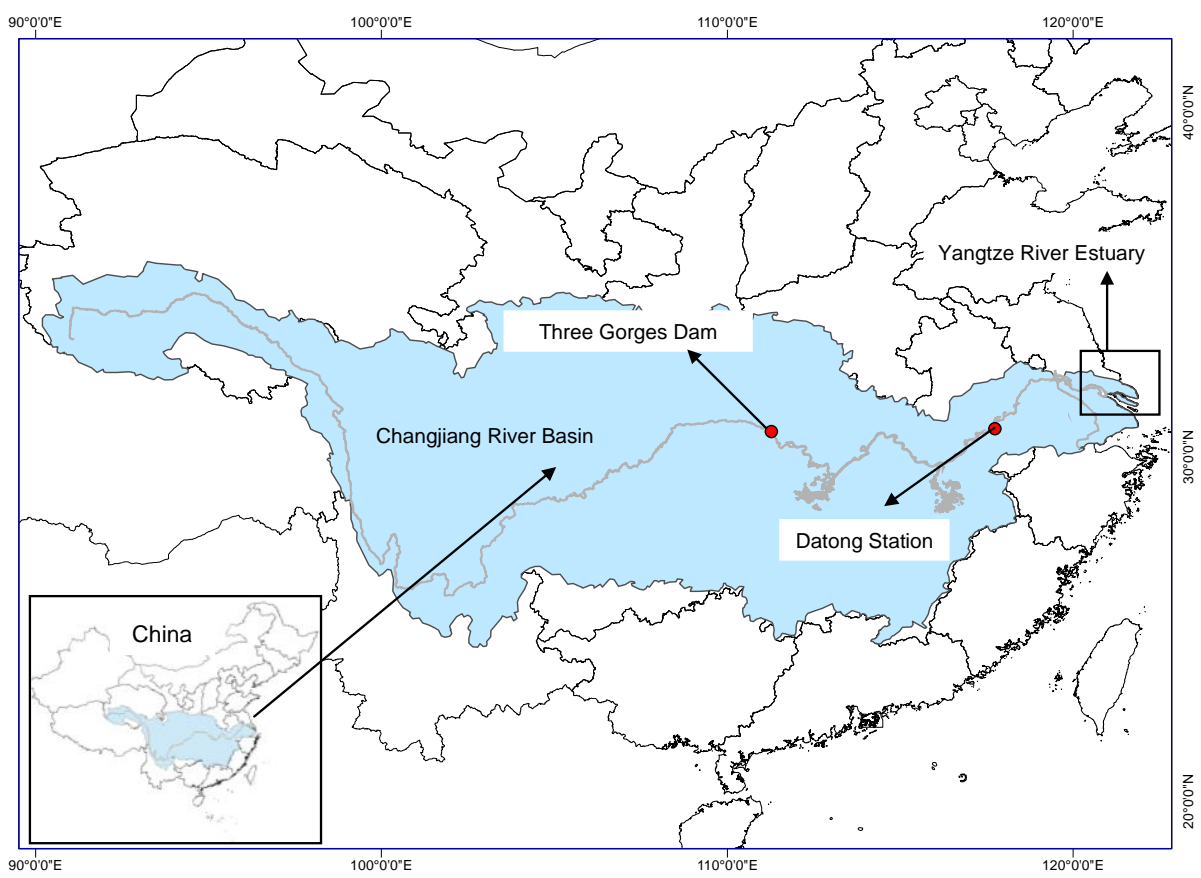

Figure 1. Location of Yangtze River Estuary, Three Gorges Dam and Datong Station.

Gorges Project, the river level in the estuary fell 20 centimeters monthly on average, the saline water intrusion intensified, and the soil and groundwater salinity were aggravated ( $\mathrm{Yu}$ et al., 2009). Probable impact factors of soil salinity were analyzed (Zhang et al., 2010) and selected to make prediction of soil salinity in North Branch of the YRE, and acceptable results were obtained (Yu et al., 2008). Providing the current hydrological regime of the estuary, the systematic impact study of the runoff from the upper reaches on salt-water dynamics and soil salinity in North Branch estuary is quite important and needs to be carried out.

\section{Material and Methods}

\subsection{Study Area}

The study area is located in Qidong county $\left(31^{\circ} 41^{\prime} \sim\right.$ $32^{\circ} 06^{\prime}, 121^{\circ} 25^{\prime} \sim 121^{\circ} 54^{\prime}$ ) on the Yangtze River bank and the crossing of China East Sea and Yellow Sea, which belongs to the estuary area of the North Branch of the Yangtze River. The flow diversion ratio of the north branch is lower than 5\% (Chen et al, 2011), which could result in high risks of saline water intrusion and soil salinization in the North branch. Based on this background, the north branch area was selected as the study site in the estuary in this paper for assessing the impact of the impoundment of the TGR on estuarine salt-water dynamics and soil salinity.

The north and East sides of the study area are surrounded by the sea, and it borders on Chongming Island in the south, and borders Haimen County in the east. The study area is located in mid latitude, and belongs to north subtropical climate zone. It has four distinctive seasons, mild climate, rich heat and abundant rainfall. The average annual rainfall in the area is $1031.1 \mathrm{~mm}$, and it is unevenly distributed during the whole year. The rainfall in January and February is less than $50 \mathrm{~mm}$, but in June, July and October the rainfall is close to $40 \%$ of the annual rainfall. The relative change rate of precipitation is high, and the relative variation of annual mean precipitation is 16 $18 \%$. The average annual evaporation rate is $1364 \mathrm{~mm}$, which is $29.2 \%$ higher than that of the same period of 1055.8 , and evaporation precipitation ratio is 1.29 . The average temperature of this region is $10 \sim 13$ centigrade.

The Yangtze River boasts the longest river in China and also the world's third largest river. Location of the TGD, YRE and Datong station was showed in Figure 1. The TGR is located in the upper reaches of the Yangtze River, and it is about 1800 $\mathrm{km}$ away from the estuary. Datong hydrological station $(\mathrm{N}$ $30.767^{\circ}, \mathrm{E} 117.617^{\circ}$ ), located $1221 \mathrm{~km}$ downstream of TGR and $624 \mathrm{~km}$ upstream of the entrance to East China Sea, is the last hydrologic station in the lower reaches of the Yangtze River without influence of tide and serves as the controlling station for the measurements of the Yangtze River water into the sea (Yang et al., 2002). It has systematic hydrological data, and river runoff at Datong hydrological station is commonly used on behalf of the runoff into the sea. Santiao station is the water level station in the estuary regions, with the distance of about $22 \mathrm{~km}$ to the entrance to East China Sea in the north branch of YRE.

\subsection{Field Monitoring}

Long term set-point monitoring section was set in the study area along the Yangtze River in the North Branch estuary as showed in Figure 2, with the distances of about $22 \mathrm{~km}$ to the 


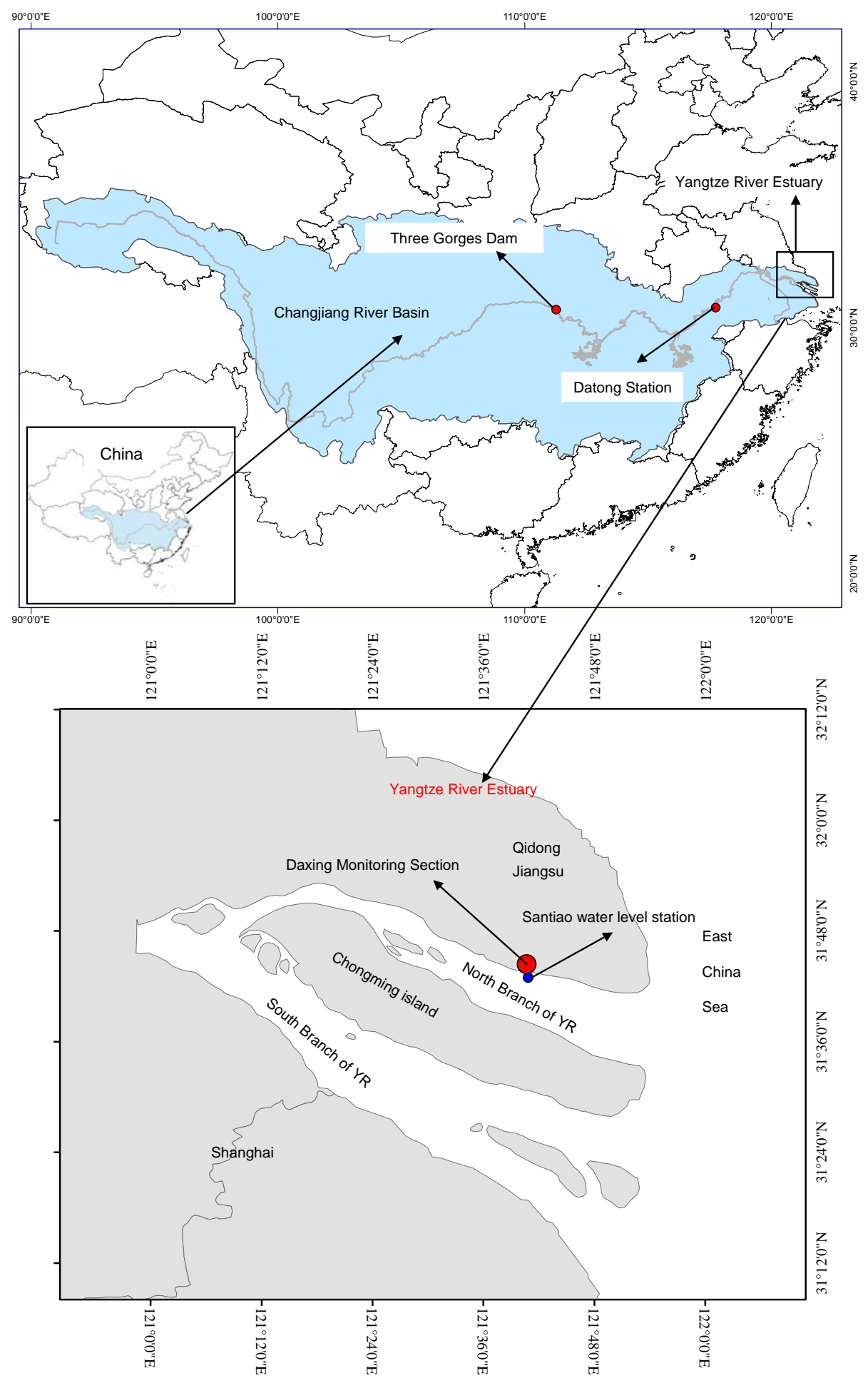

Figure 2. Location of the study site and monitoring sections arranged in the Yangtze River estuary.

entrance of the sea, which is called Daxing Section (DXS). DXS located near the entrance of the sea, so the salt-water dynamics here were sensitive to the runoff changes and seawater intrusion.

At the monitoring section, the river water salinity, ground- water salinity and soil salinity were monitored every five days. Data of water level, runoff and reservoir discharge were collected from relevant organizations listed in part 2.3. Water salinity was measured by CTD Diver provided by Schlumberger Water Services. Soil salinity was measured by TYC-2 salt sen- 
sors (Institute of Soil Science, Chinese Academy of Sciences, China) installed in soil. River salinity, groundwater salinity and soil salinity was monitored from the year 1998 to 2013 .

\subsection{Data Collection and Data Analysis}

Data of daily river flow at Datong station were collected from the web server of Yangtze River Hydrology and used in this study. Supported and quality controlled by Water Resources Department of Jiangsu Province, data of daily high and low tidal levels each day at Santiao station were collected and utilized. Data of daily reservoir inflow, outflow and water level of TGR were collected from the web server of China Three Gorges Corporation.

Providing reservoir discharge was the important factor affecting the estuary salt-water factors, correlation analysis between reservoir discharge and estuarine salt-water factors were carried out, in order to find the possible relationship between the upstream flow and the downstream soil salinity. In this paper, influence of impoundment process of the TGR on the river runoff, river water level and river salinity in the estuary was discussed in detail, and the impact of the TGR on river water level and river salinity were assessed. Then, impact of the river runoff on the groundwater salinity was analyzed. Finally, the impact of groundwater salinity on soil salinity was discussed. In present paper, classical statistical analysis and regression models were performed in the statistic software SPSS. All the abbreviations were showed in Table 1.

Table 1. Abbreviations in the Paper

\begin{tabular}{ll}
\hline & Abbreviation \\
\hline Three Gorges Project & TGP \\
Three Gorges Dam & TGD \\
Three Gorges Reservoir & TGR \\
Yangtze River & YR \\
Yangtze River Estuary & YRE \\
Daxing Section & DXS \\
Electrical Conductivity & EC \\
Impoundment Process & IP \\
Non-impoundment Process & NIP \\
\hline
\end{tabular}

\section{Result and Discussions}

\subsection{Impact Analysis of Impoundment Process of TGR on the Reservoir Discharge}

Impoundment of the TGR changes the annual monthly runoff distribution, and will interrupt salt-water balance by altering the seasonal variations of river runoff and water level characteristics in the estuary. River runoff into the sea may be influenced by impoundment process of the TGP in fall, which may cause seawater intrusion during water storage period and increase the risk of estuarine seawater intrusion.

Impoundment of TGD during the flood recession period in the third phase first started in 2006 when the reservoir water level increased from 135 to $156 \mathrm{~m}$. Impoundment of TGD in flood recession periods of $2007 \sim 2009$ led the reservoir water level reaching $156 \mathrm{~m}, 172.8 \mathrm{~m}$ and $170.9 \mathrm{~m}$, respectively. The TGR has completed the target of 175 meters of trial impounding since the year 2010. Water level variation of the reservoir was closely related to the flow discharge decrease during the water storage period according to Figure 3 . It can be concluded that the more water the reservoir stored, the less flow would be discharged.

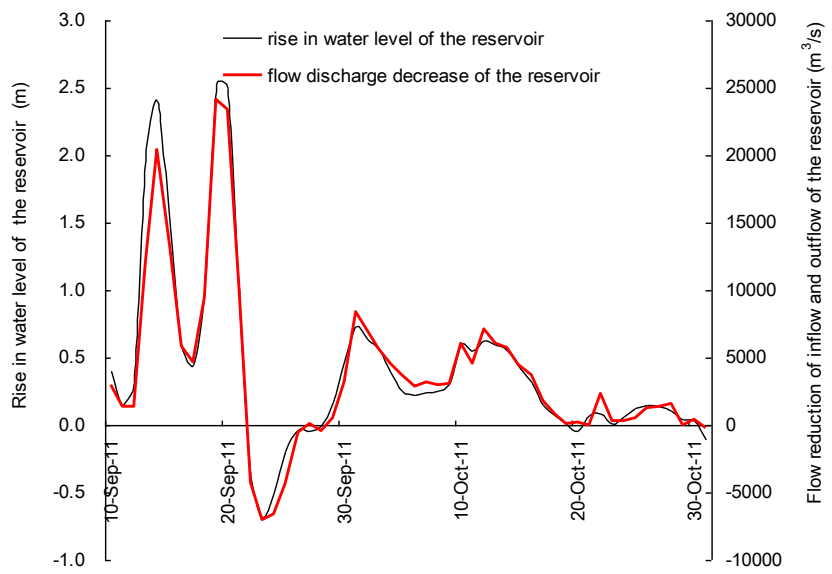

Figure 3. Variations of reservoir level and flow discharge decrease of the TGR.

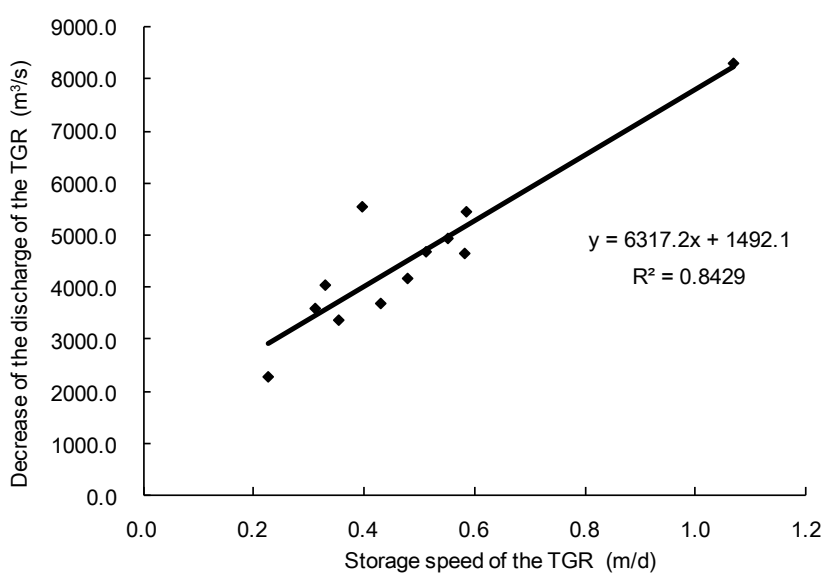

Figure 4. Correlation between average water storage speed and flow reduction of the TGR during impoundment period from year 2006 to 2018 .

We also found the connection between the water storage process and the flow discharge decrease. There was a significant positive correlation between the water storage speed and the decrease of discharge in the TGR (Figure 4). As the water storage speed increase, the discharge of TGR will decrease. Conclusion could be drawn that water storage speed of the reservoir was the main factor affecting the reservoir discharge.

The water storage speed was an important factor that represented TGP water storage characteristic, thus it could be concluded that the reservoir discharge was mainly determined by the TGP impoundment process. The storage speed was $1.1 \mathrm{~m} / \mathrm{d}$ during the storage process in 2008 , which was the highest stor- 
age speed in all the impoundment years, and discharge decrease of the TGR reached $8300 \mathrm{~m}^{3} / \mathrm{s}$ during the water storage period. It caused great changes of the reservoir discharge, which gave rise to a large decline of the river flow in the lower reaches of the Yangtze River. Relevant research results suggested preventing estuarine saline water intrusion by guaranteeing the average daily increase of TGR water level lower than $1.11 \mathrm{~m} /$ day during impounding period of TGD (Yu et al, 2014). Meanwhile, the reservoir discharge owing to impoundment process in most storage years ranged from 2000 to $6000 \mathrm{~m}^{3} / \mathrm{s}$. A large drop in flow will lead to a sharp drop in downstream river flow, which would result in a change in downstream salt-water balance.

\subsection{Impact of Impoundment Process of TGR on the Flow into the Sea in the Estuary}

The variation of the Yangtze River discharge under the dam is transmitted through the river to the lower reaches and to the estuary. Datong hydrologic station is the last permanent station in the main stream of the Yangtze River, which has systematic hydrological data, and river runoff at Datong is commonly used on behalf of the runoff into the sea. In this paper Datong runoff is used as the runoff into the sea in the estuary.

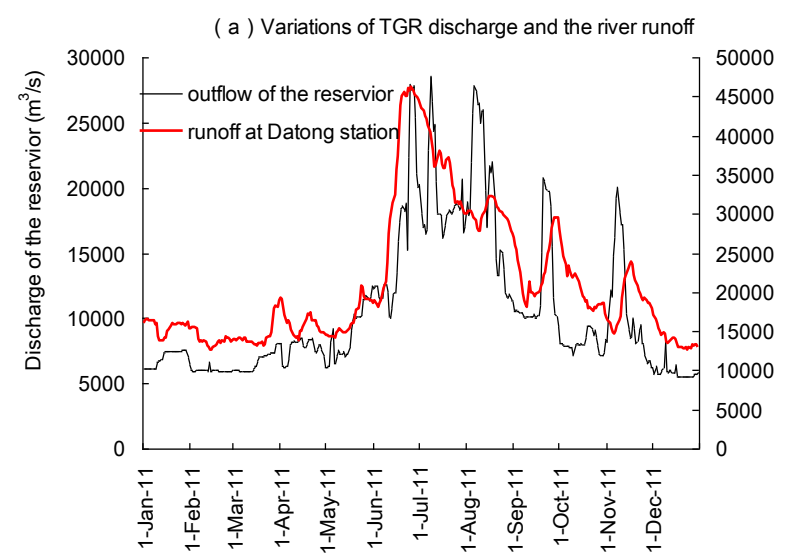

( b ) Correlation between the TGR discharge and river runoff

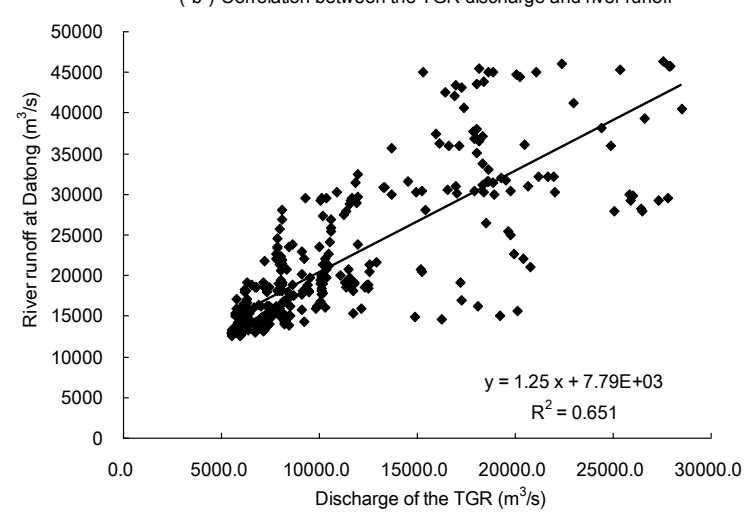

Figure 5. (a) Variations and the TGR water discharge and the river flow at Datong in 2011; (b) correlation between the TGR water discharge and the river flow at Datong in 2011.

In Figure 5(a), variations of Datong runoff and discharge of the TGR followed the same rule. And significant correlation was found between Datong runoff and discharge of the TGR, as correlation was significant at the 0.01 level (2-tailed), which suggested that river runoff at Datong station was greatly influenced by impoundment process of the TGR. As the discharge was determined by the water storage process of the TGR, the Datong runoff was indirectly affected by the TGR impoundment process. From the variations of the runoff and discharge of the TGR in 2011, river flow at Datong was influenced by the reservoir discharge, and the gradient were around 1 (Figure $5(b)$ ), which indicated that the change of water storage in the TGR determined the change of Datong runoff.

As there was significant linear correlation between discharge of the TGR and Datong flow from above analysis, and in order to understand the impact of the TGR on Datong flow deeply, we have studied the lag time of the influence of the outflow of the TGR on the Datong flow in the downstream. The optimum lag time was determined by the correlation coefficient between the delayed discharge of the TGR and river flow at Datong station. When the correlation coefficient achieved the maximum value or inflection point, the impact reached the maximum and the corresponding time is the lag time. We analyzed the relationships between discharge from the TGR and Datong runoff during storage period of 2011, 2012 and 2018, which represented different hydrological years type, and results consistently showed that the lag time was $8 \sim 9$ days (Figure 6).

Take 2011 as an example, the lag time was 8 days, and the correlation equation between the delayed discharge of the TGR and Datong runoff during the storage period was listed as below:

$y=0.9707 x+9283.3 \mathrm{R}^{* *}=0.826$

where $y$ is the Datong flow, and $x$ is the 8 days delayed discharge of the TGR. (** denotes 0.05 confidence level under $t$ test)

If there was no water storage process, $y$ was the Reservoir inflow, and $x$ could represent Datong runoff under no water storage process. The correlation equation was applied to simulate Datong runoff under no water storage process using Reservoir inflow data (Figure 7). We can see from Figure 7 that if there was no water storage process, river runoff at Datong would have been much higher than that under water storage process. And the river flow decrease with or without water storage was closely related to the Reservoir storage process, and conclusion could be drawn that the river flow change with or without water storage was determined by the reservoir impoundment process.

The Reservoir storage was linearly correlated with the reduction of the Datong runoff. It could be clearly stated that the impoundment of the TGR directly caused the reduction of the Datong runoff. The discharge decrease of the reservoir reached $3600 \mathrm{~m}^{3} / \mathrm{s}$ during the impoundment period in 2011, and it would cause about $3500 \mathrm{~m}^{3} / \mathrm{s}$ flow decline at Datong station with 8 days lag. About $17 \%$ of the water flow was lost at Datong station as the result of the TGR impoundment process. 
(a) Lag time in 2011

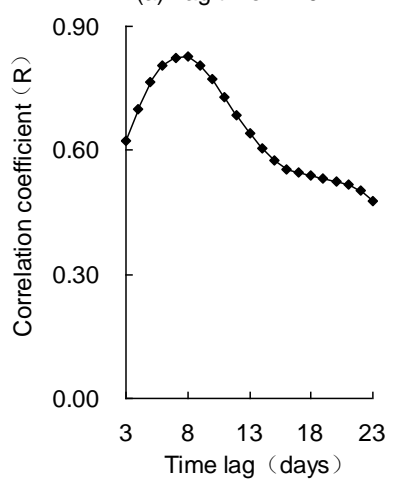

(b) Lag time in 2012

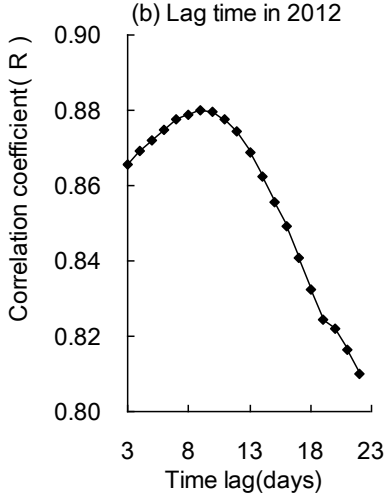

(c) Lag time in 2018

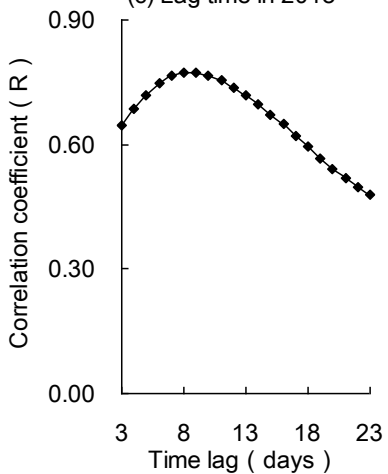

Figure 6. Lag time of the TGR's impact on the Datong runoff in (a) 2011, (b) 2012 and (c) 2018.

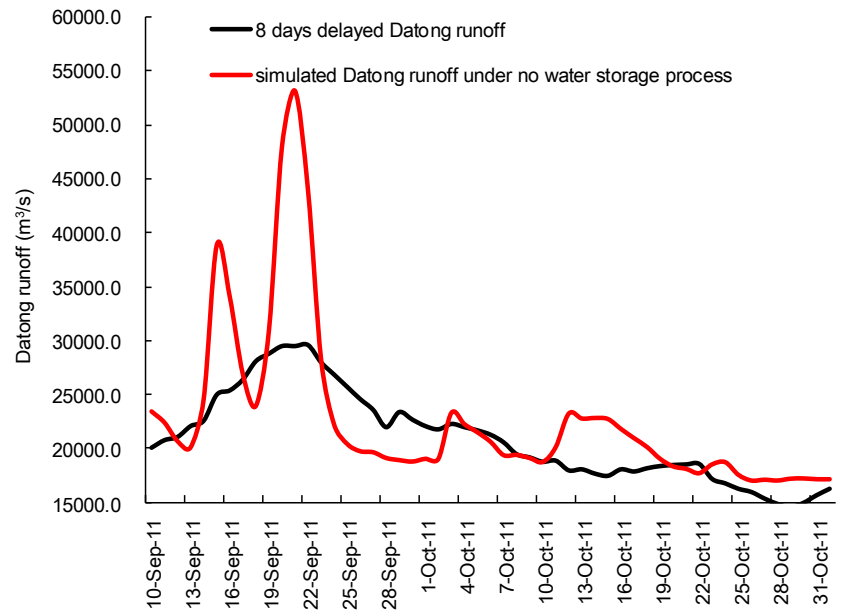

Figure 7. Datong Flow variations under Water Storage and No Water Storage Conditions.

\subsection{Impact of Impoundment Process of TGR on the Water Level in the Estuary}

Santiao station is the water level station in the estuary, with the distance of about $22 \mathrm{~km}$ to the entrance to the sea in the estuary. Reduction of the water level at Santiao station will increase the risk of estuarine seawater intrusion. Data analysis showed that there was a significant positive correlation between Datong runoff and estuarine water level (Figure 8), which suggested that variation of water level was certainly affected by river runoff. It can be inferred that runoff at Datong station affected the water level change in the estuary, and therefore the impoundment process of the TGR indirectly affected estuarine water level by influencing the change of Datong discharge.

In order to seek a more detailed understanding of the impact of the river runoff at Datong on the estuarine water level, lag time of the Datong runoff's impact on the estuarine river water level was studied. Correlation between delayed water level of Santiao station in the estuary and Datong runoff was calculated. The optimum lag time was determined by the correlation coefficient between the delayed estuarine water level and Datong flow. When the correlation coefficient achieved maximum or inflection point, the impact reached the maximum and the corresponding time was the lag time. We can see from Figure 9 that the optimum lag time of Santiao station was 13 days, and it can be inferred that the Datong runoff had the greatest impact on the estuarine river water level at the lag of 13 days. It could be concluded that the lag time of the influence of the impoundment process of the TGR on the estuarine water level is about 20 days, which was consistent with relevant research results in this area (Cao et al, 2006; Chen, 2010; Yu et al, 2014).

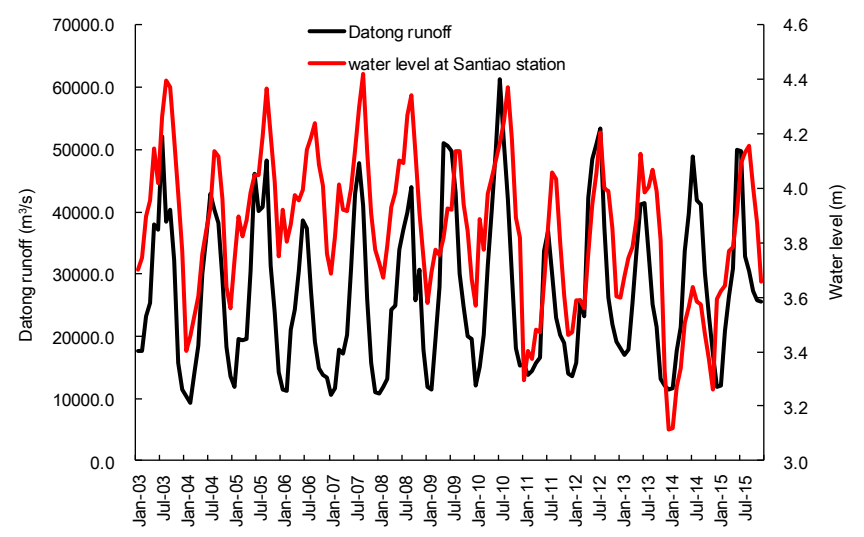

Figure 8. Variations of Datong runoff and water level at Santiao station.

\subsection{Impact of the TGP on River Salinity and Risk Assessment of Impact of the TGR on the River Salinity in the Estuary}

3.4.1. Impact of the TGR on River Salinity in the Estuary

Changes of the Yangtze River salinity and range of seawater intrusion was primarily determined by the upstream runoff. Impact of the Yangtze River runoff on the river salinity in coastal regions varies among seasons. According to the statistical results and Figure 10(a), there was close connection between the river runoff at Datong and the Yangtze River salinity in the estuary. Salinity of the Yangtze River water was significantly correlated with the river runoff at Datong (Figure 10(b)), 
which suggested that the river runoff at Datong may have certain impact on the river salinity in the estuary. This result validated the conclusion that Datong discharge reduced estuarine water level and led to seawater intrusion.

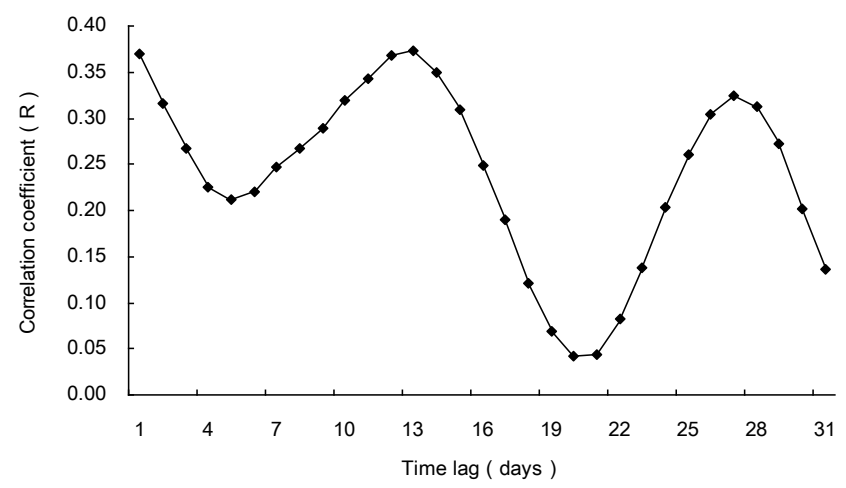

Figure 9. Lag time of the Datong runoff's impact on the estuarine river water level at Santiao station.

(a) Variations of Datong runoff and the Yangtze River salinity
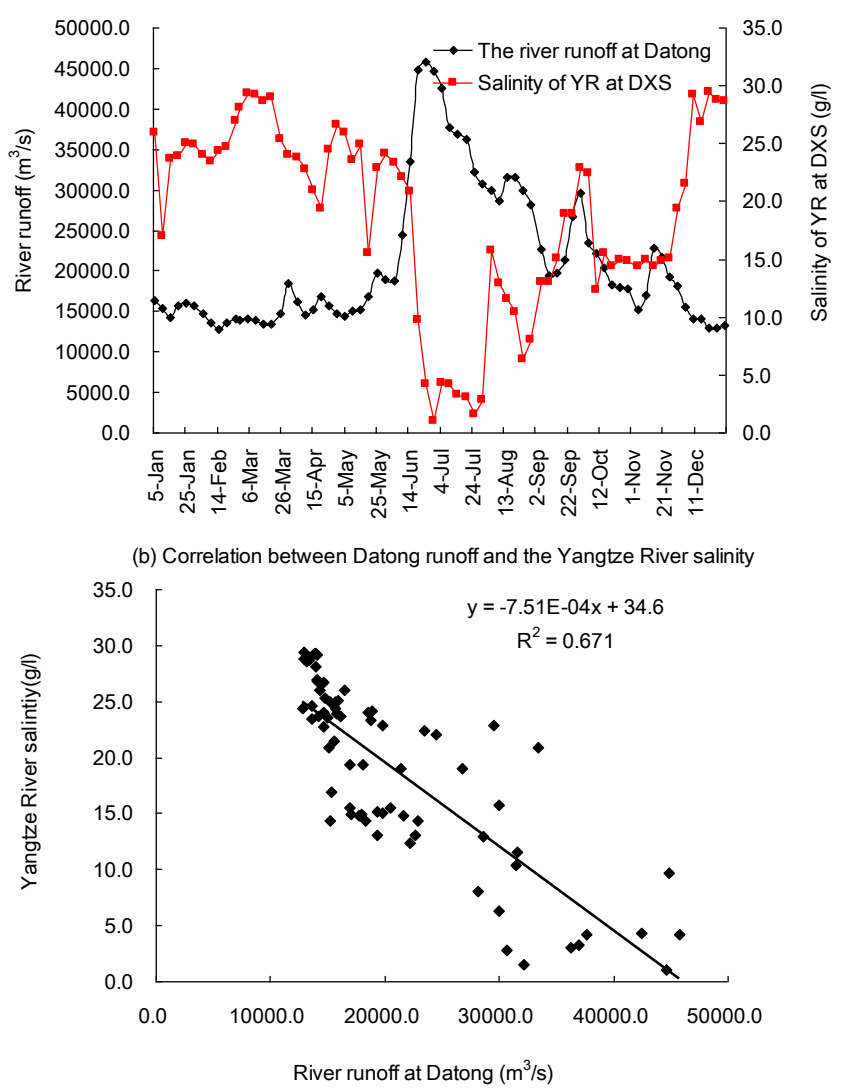

Figure 10. (a) Variations of the river runoff at Datong and the Yangtze River salinity in the estuary; (b) correlation between river runoff at Datong and the Yangtze River salinity.

It can be inferred that Datong runoff affected the process of seawater intrusion in the estuary by influencing the estuarine water level. To further validate the conclusion and deeply understand the response time of seawater intrusion to Datong runoff, impact analysis using the moving average data of Datong runoff and the Yangtze River salinity data at DXS was applied to investigate the lag of the effect time, and the regression equations were listed in Table 1 . We can see from the analysis concerning the time lag of impact of the river runoff on the river salinity of DXS in Table 2, correlation coefficients showed a downward trend when the lag time exceeded $15 \sim 20$ days. The correlation coefficient reached the maximum values on the time lag of about 15 days at DXS. Conclusion could be drawn that the greatest impact of the river runoff on the salinity of the Yangtze River at DXS in the estuary occurred at the lag of 15 days. Although there is a slight lag of impact on the river salinity, the influence of Datong runoff on the river salinity was basically similar to the influence of discharge at Datong on water level in the estuary which was discussed in part 3.3.

\subsubsection{Risk Assessment of Impact of the TGR on the River} Salinity in the Estuary

From the analysis discussed above, the TGR discharge affected the variations of Datong runoff, and the water level and the river salinity in the estuary were determined by the Datong runoff. Therefore, the water level and the river salinity were indirectly influenced the impoundment of the TGR. We established several equations to study the degree of the influence of the TGR on the river salinity and the water level in the estuary.

The regression model between the estuarine water level and Datong runoff was established (Equation 2) below using the optimum lag time data. The average flow reduction during the impoundment period in 2011 was about $3600 \mathrm{~m}^{3} / \mathrm{s}$, and it would cause about $3500 \mathrm{~m}^{3} / \mathrm{s}$ flow decline at Datong station with 8 days lag (Equation 1). It will result in $15.6 \mathrm{~cm}$ drop in the water level in the estuary. Reduction of the water level at Santiao station will increase the risk of estuarine seawater intrusion. In this case, seawater intrusion would occur more severely, and the risk of soil salinization in the estuary would increase:

$y=4.46 \mathrm{E}^{-05} x+2.80 \mathrm{R}^{* *}=0.372$

$y$ represents the river flow at Datong station $\left(\mathrm{m}^{3} / \mathrm{s}\right), x$ represents 13 days delayed water level in the estuary $(\mathrm{m})$. (**hereafter denotes 0.05 confidence level under $t$ test)

During the impoundment period in $2011,3600 \mathrm{~m}^{3} / \mathrm{s}$ flow reduction of the TGR discharge will cause about $4.26 \mathrm{mS} / \mathrm{cm}$ increase in river EC at DXS which is $22 \mathrm{~km}$ to the entrance to the sea. The increase of the river water salinity indicates the increase of intensity and risk of seawater intrusion in the estuary. It will lead to further expansion of seawater intrusion in the estuary:

$y=-1.22 \mathrm{E}^{-03} x+52.7 \mathrm{R}^{* *}=0.893$

$y$ represents the river $\mathrm{EC}(\mathrm{mS} / \mathrm{cm})$ in DXS, and $x$ represents the Datong runoff $\left(\mathrm{m}^{3} / \mathrm{s}\right)$. (**hereafter denotes 0.05 confidence level under $t$ test). 
Table 2. Time Lag Analysis of Impact of the River Runoff at Datong on Salinity of the Yangtze River

\begin{tabular}{lll}
\hline 5 days average Datong runoff $(x)$ & Salinity of the Yangtze River at DXS $(y)$ & Correlation coefficient \\
\hline synchronous & $y=-1.07 \mathrm{E}-03 x+49.2$ & $0.822^{*}$ \\
Lag of 10 days & $y=-1.19 \mathrm{E}-03 x+51.9$ & $0.883^{*}$ \\
Lag of 15 days & $y=-1.22 \mathrm{E}-03 x+52.7$ & $0.893^{*}$ \\
Lag of 20 days & $y=-1.25 \mathrm{E}-03 x+53.3$ & $0.893^{*}$ \\
Lag of 25 days & $y=-1.27 \mathrm{E}-03 x+53.7$ & $0.888^{*}$ \\
\hline
\end{tabular}

* denotes 0.05 confidence level under $t$ test

Table 3. Correlation Coefficient between Salinity of the Yangtze River and Groundwater

\begin{tabular}{llll}
\hline DXS & Monitoring Point 1 & Monitoring Point 2 & Monitoring Point 3 \\
\hline Salinity of the Yangtze River & $0.453^{*}$ & $0.322^{*}$ & $0.267^{*}$ \\
\hline * denotes 0.05 confidence level under $t$ test. &
\end{tabular}

As a result, discharge decrease of the TGR reached 3600 $\mathrm{m}^{3} / \mathrm{s}$ during the impoundment period in 2011 , and it would cause about $3500 \mathrm{~m}^{3} / \mathrm{s}$ flow decline at Datong station with 8 days lag. Under this circumstance, it will result in $15.6 \mathrm{~cm}$ drop in the water level and $4.26 \mathrm{mS} / \mathrm{cm}$ increase in river EC in the estuary, which indicated the increase of intensity and risk of seawater intrusion in the estuary.

\subsection{Impact of the TGP on Groundwater Salinity in the Estuary}

The impact of saltwater intrusion on soil is mainly through its impact on the river and groundwater salinity. With the increase of groundwater salinity, soil salt accumulates and soil salinization becomes a serious problem. Seawater will flow up along the river channel from the estuary under the help of tide, and affect the Yangtze River salinity by its flowing path upward the river, which is the main source of the groundwater salinity. There were similar trends between the salinity of the Yangtze River and the groundwater from the monitoring data, and groundwater salinity increased with the increase of salinity of the Yangtze River water as shown in Figure 11. A significant positive correlation between the two factors was found, which revealed close hydraulic connections between the Yangtze River and groundwater in the estuary.

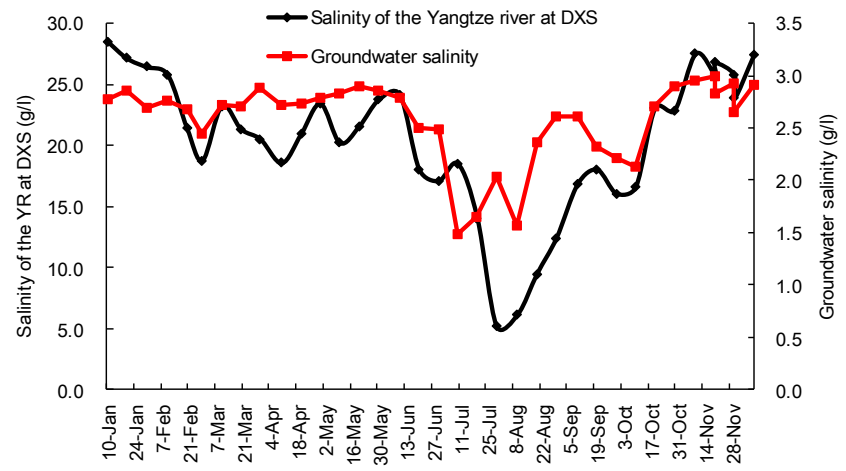

Figure 11. Variations of the Yangtze River salinity and groundwater salinity in the estuary.

At the same time, correlation analysis between the salinity of the Yangtze River and salinity of monitoring points of different distances to the bank of the Yangtze River was completed in Table 3 and result showed that groundwater salinity nearest to the bank of the Yangtze River was most significantly correlated with water salinity of the Yangtze River. That is to say, influence of water salinity of the Yangtze River on groundwater salinity increased as the distance to the river bank became smaller.

\subsection{Impact of Groundwater Salinity on Soil Salinity in the Estuary}

Owing to the impoundment of the TGP, decrease of the river runoff from the upper reaches will intensify seawater intrusion and soil salinization, and salt in groundwater is the main source of soil salinity. Soil salinity is relatively low when groundwater salinity is low, while it becomes higher in case of high groundwater salinity, shallow groundwater level and intense evaporation. We can see from the monitoring results in Figure 12 that soil EC at different depths was significantly correlated with groundwater salinity. According to the correlation analysis between groundwater salinity and soil salinity in different depths showed in Figure 12, more significant correlation exited between groundwater salinity and salt salinity in deep soil layers. In this part soil salinity at the depth of $120 \mathrm{~cm}$ displayed the most significant correlation relationship with groundwater, the second is the $60 \mathrm{~cm}$ soil layer, and in $40 \mathrm{~cm}$ depth of soil, the correlation coefficient also exceeded 0.80 , which also showed the strong effect of groundwater on the soil. In the estuary, shallow groundwater makes soil salinity of the upper layers more easily affected by groundwater than that in deep groundwater conditions.

\subsection{Comparative Analysis of Factors Affecting Salt-Water Dynamics under Impoundment and Non-Impoundment Conditions}

In order to see the difference under impoundment process, the average of factors affecting salt-water dynamics were compared under impoundment years and non-impoundment years from 1998 to 2012.

Annual mean runoff under impoundment process (IP) and non-impoundment process (NIP) were similar, but there are 
(a) Soil EC at $20 \mathrm{~cm}$ depth

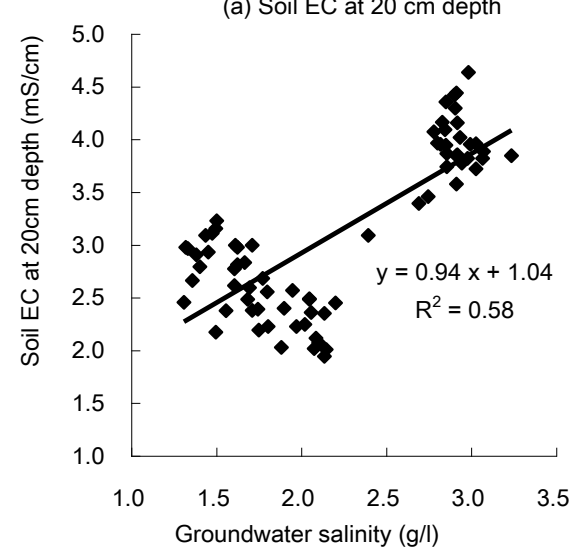

(c) Soil EC at $60 \mathrm{~cm}$ depth

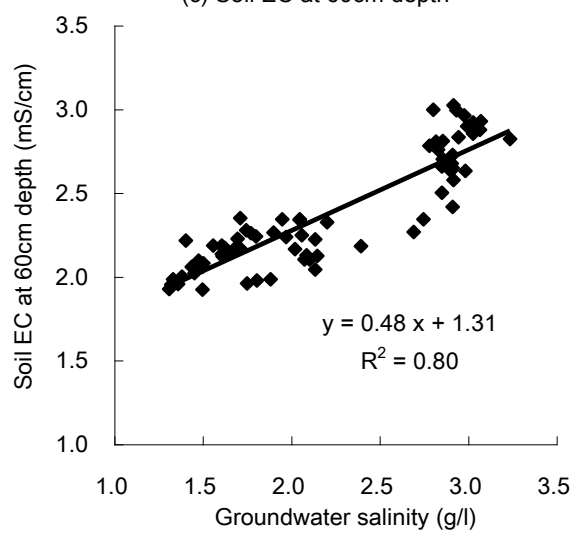

(b) Soil EC at $40 \mathrm{~cm}$ depth

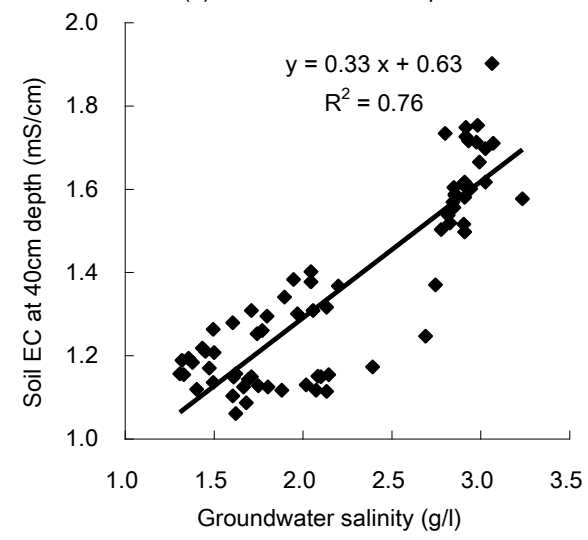

(d) Soil EC at $120 \mathrm{~cm}$ depth

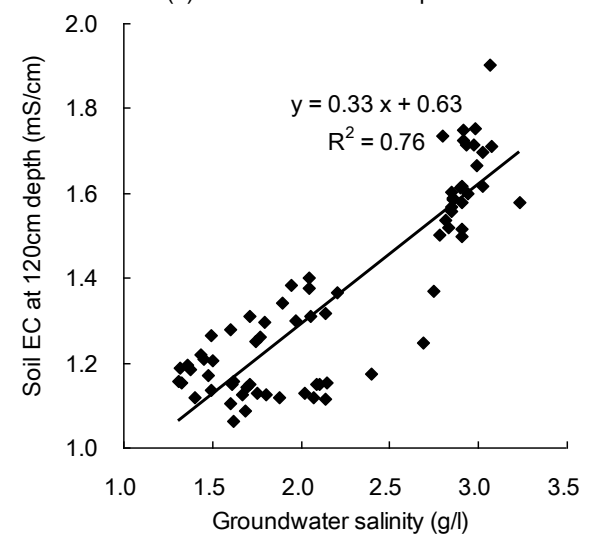

Figure 12. Scatter diagrams of groundwater salinity and soil EC at (a) $20 \mathrm{~cm}$, (b) $40 \mathrm{~cm}$ and (c) $60 \mathrm{~cm}$ depth.

differences in annual distribution of runoff. Runoff of IP from March to June was higher than that of NIP, while runoff of IP from September to October was much lower than that of NIP, and especially in September (Figure 13(a)). The Yangtze River level showed similar trend as the runoff, and the biggest difference of water level existed in September (Figure 13(b)). The storage period of the TGR is from September to October, which is consistent with this period. And the discharge process is in the first half year, and therefore the river salinity of NIP was higher than that of IP in the first half year. The Yangtze River salinity of IP was lower than that of NIP in the first half year, while it was higher than that of NIP in the autumn (Figure 13(c)). And Groundwater depth of IP became shallower (Figure 13(d)) and groundwater salinity of IP became higher than that of NIP (Figure 13(e)). Groundwater depth and groundwater salinity were two important factors affecting soil salinity, and as a result soil salinity of IP performed higher than that of NIP (Figure 13(f)). From all the monitoring results, it could be inferred that the impoundment process has a certain impact on the river water level and salinity, groundwater depth and salinity, and also soil salinity in the estuary.

\section{Conclusions}

Impoundment of the TGP played an essential role in in- fluencing the estuarine salt-water dynamics and soil salinity. Impact Study of the impoundment process on the salt-water dynamics and soil salinity in the estuary were developed and several results were obtained from this research. Results showed that the estuarine runoff was affected by the impoundment process, and the estuarine runoff was one of the most important factors that influenced the salinity dynamics of water and soil in the estuary.

It was indicated that water storage speed of the reservoir was the main factor affecting the reservoir discharge, and discharge of the TGR was closely related to Datong flow. The lag time of the influence of the outflow of the Three Gorges Reservoir on the downstream Datong flow was about $8 \sim 9$ days. And if there was no water storage process, the river flow at Datong would have been much higher than that under water storage process. River runoff at Datong also played an essential role on influencing the river water level in the estuary, and it was showed that the greatest impact on the river water level in the estuary occurred when the time lag reached 13 days It was concluded that the lag time of the influence of the impoundment process of the TGR on the estuarine water level is about 20 days, which was consistent with the impact time of the river runoff on the salinity of the Yangtze River at DXS in the estuary. The discharge decrease of the TGR reached $3600 \mathrm{~m}^{3} / \mathrm{s}$ as the result of the impoundment process in 2011, and it would 

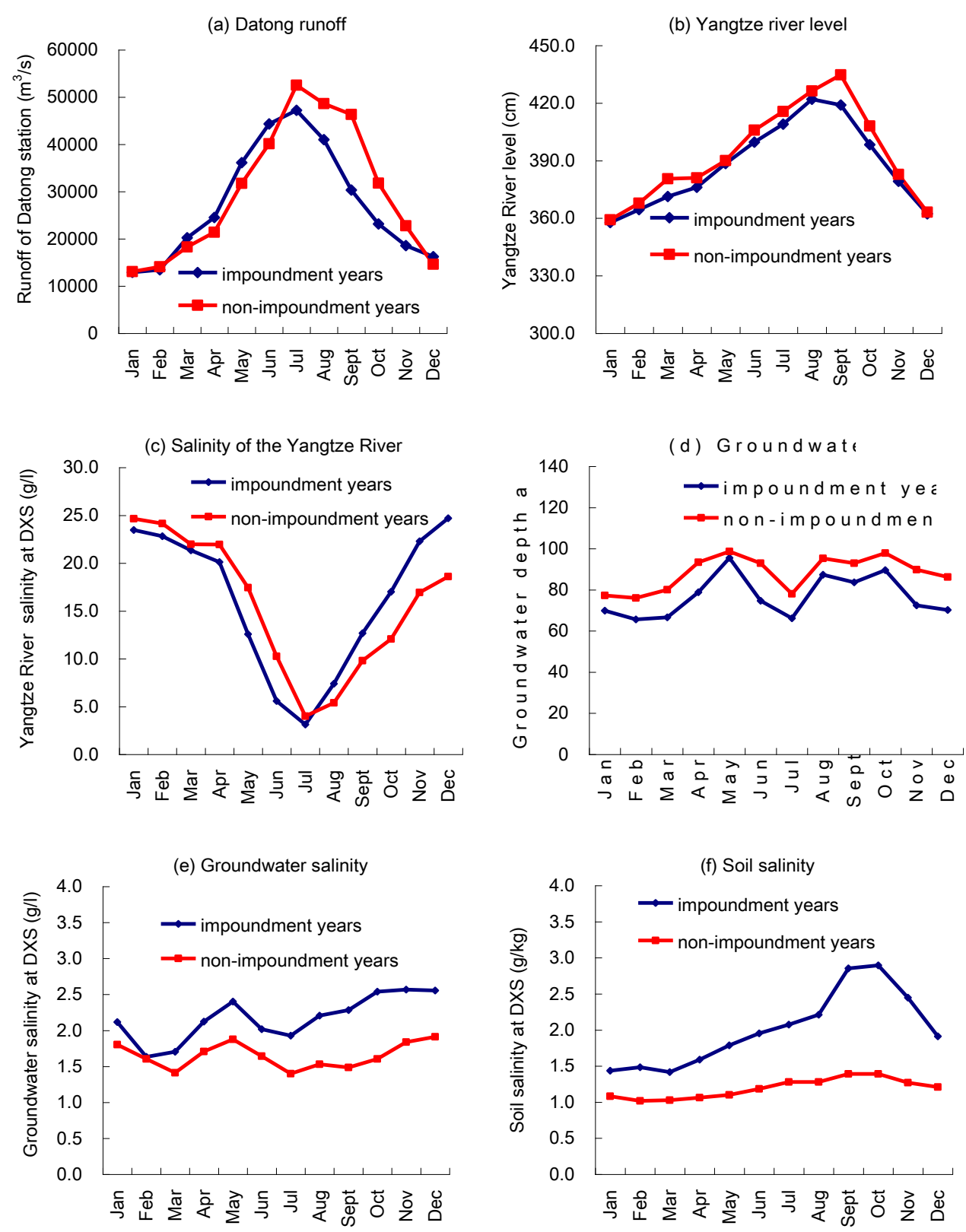

Figure 13. Comparison of river runoff at Datong (a), river water level (b), river salinity (c), groundwater depth (d), groundwater salinity (e) and soil EC of the YRE (f) between impoundment and non-impoundment years.

cause about $3500 \mathrm{~m}^{3} / \mathrm{s}$ flow decline at Datong station with 8 days lag. It will result in $15.6 \mathrm{~cm}$ drop in the water level and $4.26 \mathrm{mS} / \mathrm{cm}$ increase in river salinity in the estuary, which indicated the increase of intensity and risk of seawater intrusion in the estuary.

There was significantly positive correlation between the salinity of the Yangtze River and groundwater, and influence of the river water salinity on groundwater salinity increased gradually from the river bank to the inland. Soil salinity in different soil layers were significantly correlated to groundwater salinity, with the closest relation in the deep layers. Shallow groundwater condition made soil salinity more easily affected by groundwater. It could be inferred that the impoundment process has a certain impact on the river water level and salinity, groundwater depth and salinity, and also soil salinity in the estuary from comparative analysis of factors affecting saltwater dynamics under impoundment and non-impoundment conditions. In summary, soil and groundwater salinity are affected by the TGR, and risk of soil and groundwater salinity rise was increased under the impoundment of TGR.

Several results showed the effect of the TGP on the river flow, seawater intrusion, salt-water dynamics and soil salinity in the estuary. We have analyzed the main influencing factors of soil salinity using artificial neural network model in our fur- 
ther impact study, and the results showed that groundwater EC was the most important factor affecting soil salinity, Datong flow, groundwater depth, river water level and river water salinity were also the essential factors affecting soil salinity. However, the salt-water regime is complicated and sea-water intrusion may be caused by complex interactions among influencing factors, such as the TGP, sea level and etc. For better understanding of the impact degree of the TGP on the saltwater regime in the estuary, further and comprehensive work is also needed to be continued.

Acknowledgments. This study is financially supported by the National Natural Science Foundation Project (No. 41701253), the ecological and environmental monitoring project funded by Three Gorges Project Management Department of the Ministry of Water Resources of the People's Republic of China, the Natural Science Foundation of China (U1806215, U1906221), the National Key Research and Development Program of China (2019YFD0900702, 2019YFD1002702).

\section{References}

An, Q., Wu, Y.Q., Talor, S., and Zhao, B. (2009). Influence of the Three Gorges Project on saltwater intrusion in the Yangtze River Estuary. Environ. Geol., 56(8), 1679-1686. https://doi.org/10.1007/ s00254-008-1266-4

Arthington, A.H., King, J.M., O'Keefe, J.H., Bunn S.E., Day J.A., Pusey B., J.; Bluhdorn D.R., and Tharme R. (1991). Effects of river fragmentation on plant dispersal and riparian flora. Regul. Rivers: Res. Manage., 16(1), 83-89. https://doi.org/10.1002/(SICI)10 99-1646(200001/02)16:1<83::AID-RRR567>3.0.CO;2-T

Ashraf, M., Kahlown M.A., and Ashfaq, A. (2007). Impact of small dams on agriculture and groundwater development: A case study from Pakistan. Agric. Water Manag., 92(1-2). 90-98. https://doi.org /10.1016/j.agwat.2007.05.007

Asmal, K. (2000). Dams and development: a new framework for decision-making. The report of the World Commissions 2000.

Bobba, A.G. (2002). Numerical modelling of salt-water intrusion due to human activities and sea-level change in the Godavari Delta, India. Hydrol Sci J., 47(1), S67-S80. https://doi.org/10.1080/02626660209493023

Cai, H.Y., Zhang, X.Y., Zhang, M., Guo, L.C., Liu, F., and Yang, Q.S. (2019). Impacts of Three Gorges Dam's operation on spatial-temporal patterns of tide-river dynamics in the Yangtze River estuary, China. Ocean Sci., 15: 583-599. https://doi.org/10.5194/os-15-5832019

Cao, Y., Chen, J.Y., Zhang, E.F., Cheng, S.L., and Cao, W.C. (2006). Influence of Three Gorge reservoir filled with water on freshwater resource in the Yangtze River estuary. Adv. Water Sci., 17, 554-558.

Chai, C., Yu, Z., Shen, Z., Song, X., Cao, X., and Yao, Y. (2009). Nutrient characteristics in the Yangtze River Estuary and the adjacent East China Sea before and after impoundment of the Three Gorges Dam. Sci. Total Environ., 407(16), 4687-4695. https://doi. org/10.1016/j.scitotenv.2009.05.011

Chen, J. (2010). Approach on draught defying operation of Three Gorges Reservoir. J. Yangtze River Sci. Res. Inst., 27, 19-23.

Chen, J.Y. and Xu, H.G. (1995). Impacts of the Yangtze River ThreeGorege Hydro-engineering works on the Yangtze estuary. Resour. Environ. Yangtze Valley., 4, 242-246.

Chen, Q.J., Xu, J.Y., and Zhu, J.R. (2011). Determination of critical flow for saline water intrusion into water source area of Yangtze River estuary and guarantee measures. Yangtze River, 42, 67-72.

Chen, X., Zong, Y., Zhang, E., Xu, J., and Li, S. (2001). Human impacts on the changjiang (yangtze) river basin, china, with special reference to the impacts on the dry season water discharges into the sea. Geomorphology, 41(2), 111-123. https://doi.org/10.1016/S01 69-555X(01)00109-X

Clarkson, R.W., Childs, M.R, and Schaefer, S.A. (2000). Temperature effects of hypolimnial-release dams on early life stages of Colorado River basin big-river fishes. Copeia., 2000(2), 402-412. https://doi. org/10.1643/0045-8511(2000)000[0402:TEOHRD]2.0.CO;2

Dai, S.B., Yang, S.L., and Cai, A.M. (2008a). Impacts of dams on the sediment flux of the Pearl River, southern China. Catena., 76(1), 36-43. https://doi.org/10.1016/j.catena.2008.08.004

Dai, Z., Du, J., Li, J., Li, W., and Chen, J. (2008b). Runoff characteristics of the Changjiang River during 2006: effect of extreme drought and the impounding of the Three Gorges Dam. Geophys. Res. Lett., 35, L07406. https://doi.org/10.1029/2008GL 033456

Dehkordi, F. and Nakagoshi, N. (2004). Impact evaluation of haizuka dam on its up stream: A case study in hiroshima prefecture, Japan. Chin. Geogr. Sci. 14(4), 350-354. https://doi.org/10.1007/s11769004-0040-0

Ibàñez, C., Prat, N., and Canicio, A. (1996). Changes in the hydrology and sediment transport produced by large dams on the lower Ebro river and its estuary. Regul. Rivers: Res. Manage., 12 (1), 51 62. https://doi.org/10.1002/(SICI)1099-1646(199601)12:1<51::AI D-RRR376 > 3.0.CO;2-I

Ibàñez, C. and Prat, N.S. (2003). The environmental impact of the Spanish national hydrological plan on the lower Ebro river and delta. Int. J. Water Resour. D., 19(3), 485-500. https://doi.org/10.10 $80 / 0790062032000122934$

Jiang, C. J. and Yan, Y.X. (2003). Impact of water conservancy project on ecosystem and environment of the Yangtze River estuary. Resour. Environ. Yangtze Valley. 06, 547-551.

Jiao, N., Zhang, Y., Zeng, Y., Gardner, W. D., Mishonov, A. V., and Richardson, M. J. (2007). Ecological anomalies in the east china sea: impacts of the three gorges dam? Water Res., 41(6), 0-1293. https: //doi.org/10.1016/j.watres.2006.11.053

Kotb, T. H., Watanabe, T., Ogino, Y., and Tanji, K. K. (2000). Soil salinization in the Nile Delta and related policy issues in Egypt. Agric. Water Manag., 43(2): 239-261. https://doi.org/10.1016/S03 78-3774(99)00052-9

Liu, F., Hu, S., Guo, X., Cai, H., and Yang, Q. (2018). Recent changes in the sediment regime of the Pearl River (South China), Causes and implications for the Pearl River Delta. Hydrol. Process., 32, 17711785. https://doi.org/10.1002/hyp.11513

Lu, S., Tong, C., Lee, D.Y., Zheng, J., Shen, J., Zhang, W., and Yan, Y. (2015). Propagation of tidal waves up in yangtze estuary during the dry season. J. Geophys. Res. Oceans, 120(9), 6445-6473. https:// doi.org/10.1002/2014JC010414

Lajoie, F., Assani, A.A., Roy, A.G., and Mesfioui, M. (2007) Impacts of dams on monthly flow characteristics. The influence of watershed size and seasons. J. Hydrol., 334(3-4), 423-439. https://doi. org/10.1016/j.jhydrol.2006.10.019

Mei, X., Dai, Z., Van Gelder, P.H.A.J.M., and Gao, J. (2015). Linking three gorges dam and downstream hydrological regimes along the yangtze river, china. Earth Space Sci., 2(4). https://doi.org/10.1002/ 2014EA000052

Morais, P., Chícharo, M.A., and Chícharo, L. (2009). Changes in a temperate estuary during the filling of the biggest european dam. Sci. Total Environ., 407(7), 2245-2259. https://doi.org/10.1016/j. scitotenv. 2008.11.037

Mumba, M. and Thompson, J.R. (2005). Hydrological and ecolo- gical impacts of dams on the Kafue Flats floodplain system, south- ern Zambia. Phys. Chem. Earth, 30(6-7), 442-447. https://doi.org/10. 1016/j.pce.2005.06.009

New, T. and Xie, Z. (2008). Impacts of large dams on riparian vegetation: applying global experience to the case of China's Three Gorges Dam. Biodivers. Conserv., 17(13), 3149-3163. https://doi. org/10.1007/s10531-008-9416-2

Qiu, C. and Zhu, J.R. (2013). Influence of seasonal runoff regulation 
by the three gorges reservoir on saltwater intrusion in the changjiang river estuary. Cont. Shelf Res., 71, 16-26. https://doi.org/10. 1016/j.csr.2013.09.024

Rahman, M., Dustegir, M., Karim, R., Haque, A., Nicholls, R.J., Darby, S.E., and Akter, M. (2018). Recent sediment flux to the gangesbrahmaputra-meghna delta system. Sci. Total Environ., 643, 10541064. https://doi.org/10.1016/j.scitotenv.2018.06.147

Shahin, M. (2002). Large Dams and Storage Reservoirs, and Their Impacts. Hydrology and Water Resources of Africa, 475-508.

Wang, J., Sheng, Y., Gleason, C.J., and Wada, Y. (2013). Downstream Yangtze River levels impacted by three gorges dam. Environ. Res. Lett., 8(4), 044012. https://doi.org/10.1088/1748-9326/8/4/04 4012

White, G.F. (1988). The environmental effects of the high dam at Aswan. Environ. Sci. Policy Sust. Dev., 30 (7), 4-40. https://doi.org /10.1080/00139157.1988.9930898

Wu, H.P., Chen, J., Zeng, G.M., Xu, J.J., Sang, L.H., Liu, Q., and Ye, S.J. (2019). Effects of early dry season on habitat suitability for migratory birds in China's two largest freshwater lake wetlands after the impoundment of Three Gorges Dam. J. Environ. Inform., https: //doi.org/10.3808/jei.201900411

Yang, S.L., Zhao, Q.Y., and Belkin, I.M. (2002). Temporal variation in the sediment load of the Yangtze River and the influences of human activities. J. Hydrol. 263:56-71 https://doi.org/10.1016/S00 22-1694(02)00028-8

Yang, S.L., Zhang, J., Zhu, J., Smith, J.P., Dai, S.B., Gao, A., and Li,
P. (2005). Impact of dams on Yangtze River sediment supply to the sea and delta intertidal wetland response. J. Geophys. Res., 110 (F3), F03006. https://doi.org/10.1029/2004JF000271

Yang, S.L., Liu, Z., Dai, S.B., Gao, Z.X., Zhang, J., Wang, H.J., and Zhang, Z. (2010). Temporal variations in water resources in the yangtze river (changjiang) over the industrial period based on reconstruction of missing monthly discharges. Water Resour. Res., 46(10). https://doi.org/10.1029/2009WR008589

Yu, S.P., Yang, J.S., Liu, G.M., and Zou, P. (2008). Simulation and prediction of soil salt dynamics in the Yangtze River Estuary with BP artificial neural network. Soils, (06), 976-979.

Yu, S.P., Yang, J.S., and Liu, G.M. (2009) Impact on soil salinization in Yangtze River estuary by Three-Gorge project. J. Liaoning Tech. Univ., (06), 1013-1017.

Yu, S., Yang, J., and Liu, G. (2014). Impact assessment of Three Gorges Dam's impoundment on river dynamics in the north branch of Yangtze River estuary, China. Environ. Earth Sci., 72, 499-509. https://doi.org/10.1007/s12665-013-2971-1

Zahar, Y., Ghorbel, A., and Albergel, J. (2008). Impacts of large dams on downstream flow conditions of rivers: Aggradation and reduction of the Medjerda channel capacity downstream of the Sidi Salem dam (Tunisia). J. Hydrol., 351(3-4), 318-330. https://doi.org/10.10 16/j.jhydrol.2007.12.019

Zhang, T.J., Yang, J.S., Liu, G.M., and Yang, Q.Y. (2010). Application of grey system theory evaluating the influencing factorsof soil salinity. Chin. J. Soil Sci. (04), 793-796. 